\title{
THE ROUTLEDGE COMPANION TO DRAMATURGY
}

\author{
Edited by \\ Magda Romanska
}


First published 2014

by Routledge

2 Park Square, Milton Park, Abingdon, Oxon OX14 4RN

and by Routledge

711 Third Avenue, New York, NY 10017

Routledge is an imprint of the Taylor $\mathcal{B}$ Francis Group, an informa business

(C) 2014 Magda Romanska for selection and editorial matter; individual contributions, the contributors

The right of Magda Romanska to be identified as author of the editorial material and of the authors for their individual chapters has been asserted in accordance with sections 77 and 78 of the Copyright, Designs and Patents Act 1988.

All rights reserved. No part of this book may be reprinted or reproduced or utilised in any form or by any electronic, mechanical, or other means, now known or hereafter invented, including photocopying and recording, or in any information storage or retrieval system, without permission in writing from the publishers.

Trademark notice: Product or corporate names may be trademarks or registered trademarks, and are used only for identification and explanation without intent to infringe.

British Library Cataloguing in Publication Data

A catalogue record for this book is available from the British Library

Library of Congress Cataloguing in Publication Data

The Routledge companion to dramaturgy / [edited] by Magda Romanska. pages $\mathrm{cm}$

Includes bibliographical references and index.

1. Theater--Production and direction. 2. Dramaturges. I. Romanska, Magda, editor of compilation. II. Title.

PN2053.R78 2014

792.02'3--dc23

2014002637

ISBN: 978-0-415-65849-2 (hbk)

ISBN: 978-0-203-07594-4 (ebk)

Typeset in Goudy

by Taylor \& Francis Books 


\section{CONTENTS}

List of illustrations

\section{PART I}

World dramaturgy in the twenty-first century

1 Robert Blacker looks at the past and future of American dramaturgy JACOB GALLAGHER-ROSS AND ROBERT BLACKER

2 Contemporary new play dramaturgy in Canada BRIAN QUIRT

3 Collaborative dramaturgy in Latin American theatre MARGARITA ESPADA

4 Documentary dramaturgy in Brazil JULIE ANN WARD

5 The place of a dramaturg in twenty-first-century England DUŠKA RADOSAVLJEVIĆ

6 On German dramaturgy BERND STEGEMANN JOHANNES STIER

7 The making of La Dramaturgie in France KATE BREDESON 
8 Dramaturgy and the role of the dramaturg in Poland AGATA DABEK

MICHAEL LEONARD KERSEY MORRIS

9 The new play dramaturgy in Russia PAVEL RUDNEV

JESSICA HINDS-BOND

10 Dramaturgy in post-revolution Iran: problems and prospects MARJAN MOOSAVI

11 Performing dramaturgy in Syria: observations and interview with Mayson Ali FADI FAYAD SKEIKER

12 Official and unofficial dramaturgs: dramaturgy in China WILLIAM HUIZHU SUN

13 Dramaturgy of separated elements in the experimental Japanese theatre EIICHIRO HIRATA

14 Dramaturgy in Indian theatre: a closer view KETAKI DATTA

15 Dramaturgy in Australia and the case of Avast and Doku Rai PETER ECKERSALL

16 Dramaturgies in/of South Africa MARIÉ-HELEEN COETZEE AND ALLAN MUNRO

\section{PART II}

Dramaturgy in the age of globalization

17 The dramaturg as globalist TOM SELLAR

18 Freelance dramaturgs in the twenty-first century: journalists, advocates, and curators ANNE HAMILTON

19 The National Theatre goes international: global branding and the regions JENS PETERS 
20 From alienation to identity: transnational communication of Russian-Israeli theatre MIRIAM YAHIL-WAX

21 Intercultural dramaturgy: dramaturg as cultural liaison WALTER BYONGSOK CHON

22 The dramaturgical bridge: contextualizing foreignness in multilingual theatre DEBRA CAPLAN FAEDRA CHATARD CARPENTER

24 Transcultural dramaturgy methods JUDITH RUDAKOFF

25 The dramaturgical process and global understanding ROBYN QUICK

26 European dramaturgy in the twenty-first century: a constant movement MARIANNE VAN KERKHOVEN

\section{PART III}

Dramaturgy in motion: demolitions, definitions, and demarcations

27 Dramaturgy on shifting grounds

29 Interactual dramaturgy: intention and affect in interdisciplinary performance BRUCE BARTON

30 The expansion of the role of the dramaturg in contemporary collaborative performance SARAH SIGAL

31 Who is the dramaturg in devised theatre? TERESA STANKIEWICZ

32 Finding our hyphenates: a new era for dramaturgs JESSICA APPLEBAUM 
33 Dramaturgy as a way of looking into the spectator's aesthetic experience MILAN ZVADA

34 Dramaturgy as training: a collaborative model at Shakespeare's Globe AMY KENNY

35 The art of collaboration: on dramaturgy and directing ANNE BOGART AND JACKSON GAY

36 Dramaturgy in action ... even if it's not as a dramaturg

PART IV

Dramaturgs as artistic leaders and visionaries: privileges and responsibilities of the office

37 Dramaturgs as artistic leaders

GIDEON LESTER

38 Dramaturgical leadership and the politics of appeal in commercial theatre KEN CERNIGLIA VICKI STROICH

40 Leadership advice to a dramaturgy student ANNE CATTANEO

41 Season planning: challenges and opportunities EDW ARD SOBEL

42 The dramaturg's role in diversity and audience development JULIE FELISE DUBINER

43 Guthrie Theater's debt to women and diversity MARIANNE COMBS

44 Reimagining the literary office: designing a department that fulfills your purpose JANINE SOBECK

45 The National New Play Network Collaborative Literary Office: new tools for old tricks JASON LOEWITH AND GWYDION SUILEBHAN 


\section{PART V}

Dramaturg as mediator and context manager: transculturalism, translation, adaptation, and contextualization

46 A view from the bridge: the dramaturg's role when working on a play in translation

KATALIN TRENCSÉNYI

GITTA HONEGGER

48 The dissemination of theatrical translation ADAM VERSÉNYI

49 Literary adaptation for the stage: a primer for adaptation dramaturgs JANE BARNETTE

50 Intermingling literary and theatrical conventions TOMASZ WIŚNIEWSKI MATT DICINTIO

52 Dramaturg as context manager: a phenomenological and political practice GRAÇA P. CORREAA MARK BLY

54 Thinking like an actor: a guide for the production dramaturg ANDREW IAN CARLSON

55 The youth respondent method: new work development of Theatre for Young Audiences KRISTIN LEAHEY

\section{PART VI}

Dramaturgy among other arts: interdisciplinarity, transdisciplinarity, and transvergence

56 Complex in-betweenness of dramaturgy and performance studies MARIN BLAŽEVIĆ 
57 The dramaturg(ies) of puppetry and visual theatre DASSIA N. POSNER

60 The role of the dramaturg in the creation of new opera works ANDREW EGGERT

61 Dramaturgy and film GERRY POTTER

62 Phronesis for robots: (re)covering dramaturgy as an interdiscipline MICHAEL CHEMERS

63 Dramaturgical design of the narrative in digital games KLAUS P. JANTKE

64 New media dramaturgy

PETER ECKERSALL, HELENA GREHAN, AND EDWARD SCHEER

65 The science of dramaturgy and the dramaturgy of science JULES ODENDAHL-JAMES

\section{PART VII}

Dramaturg as systems analyst: postdramatic structures

66 Postdramatic dramaturgy

GAD KAYNAR

67 Teaching deconstructively BARBARA JOHNSON

68 EF's visit to a small planet: some questions to ask a play ELINOR FUCHS TORI HARING-SMITH

70 On dramaturgy in contemporary dance and choreography SANDRA NOETH 
71 Research, counter-text, performance: reconsidering the (textual) authority of the dramaturg D. J. HOPKINS

72 The bead diagram: a protean tool for script analysis SHELLEY ORR

73 Methods for a new dramaturgy of digital performance JODIE MCNEILLY

74 Drametrics: what dramaturgs should learn from mathematicians MAGDA ROMANSKA

75 Parallel-text analysis and practical dramaturgies TOBY MALONE

\section{PART VIII}

Dramaturg as public relations manager: immersions, talkbacks, lobby displays, and social networks

76 Dramaturgy and the immersive theatre experience ANDRÁS VISKY

78 Framing the theatrical experience: lobby displays MIRIAM WEISFELD

79 Dramaturg as public relations manager KATIE RASOR

80 Talkbacks: asking good discussion questions JODI KANTER

81 Talkbacks for "sensitive subject matter" productions: the theory and practice MARTINE KEI GREEN-ROGERS

82 Dramaturgies for the digital age ILINCA TODORUŢ

83 Digital engagement: strategies for online dramaturgy 
84 Digital dramaturgy and digital dramaturgs

85 Can technology save theatre? Tweet seats, YouTube auditions, and Facebook backstage?

RANDI ZUCKERBERG

Index 


\section{6 \\ Dramaturgy and the immersive theatre experience \\ Catherine Bouko}

The concept of immersive theatre is today growing in success, be it with artists - such as international avant-garde for commercial success such as Then She Fell by Third Rail Project (2012, New York) - or indeed with researchers. This explains why the journalist Mark Lawson has stated, "On a bad day at the Edinburgh or Manchester festivals, there were times when a critic felt dizzy nostalgia at the sight of a seat or a script." 1 The term immersion designates a multitude of different practices in various disciplinary fields: naturally cinema and video games, but equally theatre, installation art, performance, dance, and the fine arts. Due to the broad use of the concept of immersion, it is becoming increasingly metaphorical, even opaque and contradictory. In this context, to what extent does the notion of immersion constitute a paradigm, best able to take into account a certain dramaturgical specificity? What criteria constitute the necessary conditions for a paradigm of immersion, applicable to different theatrical forms?

\section{Theatrical immersion: two facets and three degrees}

Given the variations of physical and dramaturgical proximity and environmental penetration, our model of immersive theatre is centered upon three steps. This can be summed up in the following manner:

1 physical integration vs. breaking down frontality;

2 sensory and dramaturgical immersion;

a placing the immersant at the center of an environment, between simulation and representation;

b the immersant's dramaturgical integration, first-person dramaturgy;

3 immersion and spatiotemporal indeterminacy.

Each step represents a specific anchorage of the fluctuation between the real and the imaginary. Once the first stage is reached, the boundaries between the real and the imaginary are physically disturbed; the fluctuation between the real and the 
imaginary is no longer structured by physical separation. At this stage, it cannot yet be called immersion. Another level of fluctuation is achieved once the second stage is reached: the immersant is sensorially and physically plunged into an imaginary world.

The third step takes the form of absolute immersion, whereby the immersant experiences confusion between the real and the imaginary universe, even at the level of his approach to the existence of his body in the space: the body scheme can be manipulated; the ability to situate one's body in a space can be impeded. The immersion achieved in this third stage is such that even when the immersant stops cooperating, he is unable to distinguish between the real and imaginary worlds, his approach to his own body being hampered. It is hardly worth stating that such moments of immersion are temporary and very difficult to attain.

These three stages align to a certain extent with those suggested for video games by Emily Brown and Paul Cairns, ${ }^{2}$ who identify "engagement," "engrossment," and "total immersion." The second and third steps previously identified echo the two methods of operation for illusion singled out by Grau with regards to virtual space. ${ }^{3}$ The first level coincides with the classical mechanism of illusion, by which the participant consciously chooses to play along with the artificial world. The second level becomes apparent once the suggestive effects are intensified, temporarily preventing differentiation between virtual and real spaces. In this article, we will concentrate on the second step, which is at the heart of the immersive theatre experience.

\section{Step 1: physical integration vs. breaking down frontality}

Many theatrical practices described as immersive theatre cannot really be aligned with immersive theatre stricto sensus. Indeed, it is not enough just to break the frontal division between the stage and the audience in order to achieve immersion. Gareth White appears to support this idea when he states,

"Immersive theater," then, is an inviting but faulty term to use to describe the phenomena it currently designates. Immersive theatre often surrounds audience members, makes use of cleverly structured interiors and ingenious invitations for them to explore, addresses their bodily presence in the environment and its effect on sense making, and teases them with the suggestion of further depths just possibly within reach. But it has no strong claim to creating either fictional or imaginative interiors in any way that is different in kind than in more conventionally structured audience arrangements. ${ }^{4}$

Breaking down frontality is only the first step to immersive, physical integration.

\section{Step 2a: sensory immersion vs. sensory vertigo}

Dominic Arsenault and Martin Picard have identified three types of sensory immersion: visceral, contemplative, and kinaesthetic. ${ }^{5}$ These three variations can be combined in one and the same immersive experience. The sensory appeal offered to 
DRAMATURGY AND THE IMMERSIVE THEATRE EXPERIENCE

spectators does not necessarily make it an immersive experience. Mark Reaney's theatre, which is often described as an immersive experience, poses exactly this issue. His work on three-dimensional projections marked the digital theatre of the 1990s. In Wings (1996), Reaney turns to head-mounted displays with the aim of immerging the spectator in a partially virtual environment. These screen-glasses, placed as close as possible to the spectator's eyes, thus prevent any perception of distance from the piece. This technology allows the actor's presence on stage to be combined with a real-time projection of three-dimensional images. Nevertheless, this cannot really be considered as sensory immersion in a virtual environment; indeed, these three-dimensional images always fulfill a representative role, with some of them devoid of all desire for mimetic immersion.

Work on immersion generally underlines the central role of corporal appeal in creating an acute sense of being. For example, Josephine Machon ${ }^{6}$ concentrates on the visceral dimensions of immersive performance; Sarah Rubidge ${ }^{7}$ evokes the fact that certain installations appeal to what Paul Rodway calls the "intimate senses (the haptic, the kinaesthetic, the visceral, the proprioceptive)"; Frances Dyson ${ }^{8}$ demonstrates how the work of Char Davies (particularly her famous installation Osmose, 1995) frees itself from a Western, dualistic view of the world, in that she offers the experience of being dominated through breathing and balance rather than through sight; the British company Punchdrunk aims for participants to "become most aware of being in the moment."

Far from being a side effect whose purpose could be summarized as breaking the spectator's classical appeal, the immersant's sensory appeal constitutes an experience which places his body at the heart of the dramaturgy. The immersant's body experiences first hand the fluctuation between what is real and what is imaginary. In numerous immersive performances, the perceptive confusion caused by illness acts as a starting point to explore our perceptive processes and identity construction. In the Belgian company Crew's performances, the participant is plunged into a modified perception of character via a head-mounted display. The feeling of immersion essentially comes from the 360-degree vision which the display allows; the image which is projected in front of the participant's eyes follows every movement of his head. These images mix pre-recorded sequences with scenes produced with performers in real time, around the participant. One such example is in Eux (Crew, 2008), where the spectator takes on the role of a patient suffering from agnosia (a loss of recognition). Kurt Vanhoutte et al. ${ }^{10}$ have analysed how such performances transform performance space into a "transitional space" in which it becomes difficult to discern the barrier between the immediate universe and the mediatized universe.

\section{Step 2b: dramaturgical immersion vs. dramatic identification}

The stake involved in immersive theatre is in trying to achieve that delicate dramaturgical balance, which consists of linking the way in which the immersant is guided with the freedom which must be allowed him in order to appropriate the piece. Ryan ${ }^{11}$ warns against the "myth of the Holodeck," whereby interactive narratives would allow the participant to become a character in the same way as those in novels or plays. Ryan emphasizes the fact that only certain plots can come close to this myth. 
In the case of immersive theatre, we cannot talk about interactivity stricto sensus, in spite of its extensive use and fashionable state. Steve Dixon emphasizes how many displays referred to as interactive are merely reactive. ${ }^{12}$ The researcher identifies four levels of interactivity: navigation, participation, conversation, and collaboration. The variability which each immersant brings to the interactive experience increases as we pass from one level to the next. Above all, immersive theatre seems to develop strategies for navigation and participation; sequences which provoke true conversation and/or collaboration are rare. Performers will react to the immersant's dealings following a predetermined framework, in an almost identical manner for each one.

The power of many immersive plays is the way in which they exploit first-person dramaturgy centered on the exploration by a character suffering from perceptive confusion. The character embodies auto-reflexive actions: he observes the world and tries to understand how his perceptions have been modified by illness. This display allows for the achievement of a particular "internal-exploratory interactivity." 13 The enacted dimension of the dramaturgy is limited but nevertheless indispensable to the way in which the plot plays out. Immersive plays are based on constant give and take between narrative coherence and the immersant's exploratory freedom.

Crew's plays preserve the fluctuation between the real and the imaginary. In particular, this is made possible by the way in which the immersant is addressed. At the beginning of Eux, a male voice calls the immersant by his first name, at the same time as it is shown on a screen. The participant is invited to embody a character yet his personal identity is nevertheless taken into account. In immersive theatre, the pronoun "you" is frequently employed when addressing the immersant. Jeremy Douglass has shown how games use the second person to encourage an effect of identification or immersion in the first person. ${ }^{14}$ As in the digital fictions analyzed

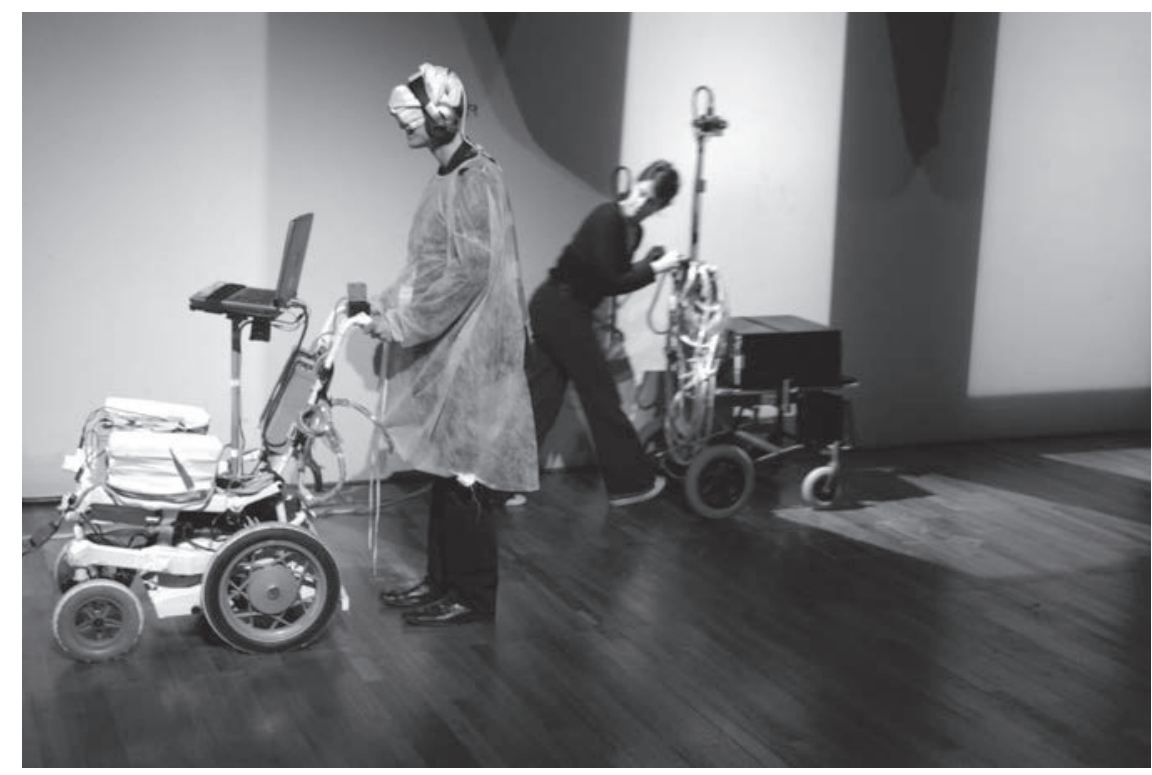

Figure 76.1 Crew and Eux by Eric Joris. (C) Eric Joris 
DRAMATURGY AND THE IMMERSIVE THEATRE EXPERIENCE

by Alice Bell and Astrid Ensslin, immersive theatre "employ[s] the textual 'you', mostly by combining actualized and fictionalized address with doubly deictic 'you', in order to blur the boundaries between game and fiction while simultaneously subverting the subjective, uncritical behavior and attitudes exhibited by readers/ players [immersants]."15

\section{Immersive fluctuations between the real and the imaginary}

Dramatic immersion distinguishes itself from literary immersion by the tangibility of the world into which the individual is plunged, as opposed to the world of literature into which the reader is absorbed. For Ryan, the latter produces an imaginary relationship with a literary world, which leads the addressee to metaphorically plunge into the tale. ${ }^{16}$ Richard Gerrig links literary immersion with the concept of "transportation," through which a reader of fiction distances himself from his immediate physical environment in order to "lose" himself in the story. ${ }^{17}$ Marie-Laure Ryan's suggested depiction of immersive theatre only takes into account the spectator's identification processes. ${ }^{18}$ The spectators (represented by the white spots plunged into the black background) remain removed from the action being played out by the actors (black spots) and maintain their role as observers. Here, immersion is simply synonymous of mental projection into the work.

Immersive theatre places the participant at the heart of a work. All the same, it abandons the exclusive search for physical and mental transportation in order to place the subject in a specifically theatrical entredeux, between adherence and denial. Rather than a difficulty to be hidden, the medium's visibility is exploited and lodges itself at the heart of this theatrical language: at particular moments, the immersant may be absorbed to the point of substituting the environment for everyday reality; the medium appears transparent and the created world seems to be offered without any intermediary. At other times, he becomes aware of the artificial nature of the world into which he is plunged and adopts a position external to the work. It is precisely this game of coming and going which constructs and deconstructs physical and mental immersion and which constitutes the specificity of immersive theatre.

Matthew Causey reminds us, "the theatre has always been virtual, a space of illusory immediacy." 19 In her study on video games, Elena Gorfinkel brings to mind the fact that immersion is not a characteristic but rather an effect which a work may produce on the participant. ${ }^{20}$ It is important to make this distinction as she explains, in part, to what extent it is impossible to establish a strict dichotomy between immersion and critical distance. According to Oliver Grau, it is not a question of "one or the other"; the relationship between immersion and critical distance depends on numerous parameters, including the participant's temperament. ${ }^{21}$ Indeed, the participant's immersion is dependent on his willingness. No matter how immersive a piece may aim to be, it will always be possible to maintain one's critical distance, thereby negating the immersion. No piece can guarantee immersion; thus our model depends not on particular pieces but rather on immersive strategies which are employed and which can be encountered in a variety of works. 
Assuming that immersive fluctuation is at the heart of all theatrical practices, we have seen to what extent it can take on an immersive specificity, which nourishes a multitude of dramaturgical explorations. For these dramaturgs, immersion makes it possible to forge an authentic type of relationship with the spectator. The passage from the notion of site-specific or site-sympathetic to the notion of immersive theatre, as in the case of Punchdrunk, highlights the change of focus from the dramaturgical space to the experience encountered by the spectator - an experience that aims to be empowering. The extreme care exercised in Punchdrunk's scenography illustrates it:

In terms of empowering the audience, those sensual details give the audience the chance to really become part of it. You can open the drawer, you can root around, see the pen that wrote that letter, smell the ink, just so that it intoxicates them, they become part of it and it has greater impact. A lot of it's to do with ... that extra sense and the power of the imagination, its smells, things that haunt you and flavour the experience. ${ }^{22}$

Beyond the writing of a dramaturgy that manipulates the boundaries between the real and the imaginary, the dramaturg now often plays a role in accompanying this embodied dramaturgical experience. Many immersive performances, such as the ones created by Crew, offer the spectator the possibility of attending the experience lived by the other spectators, in order to uncover the dramaturgical and technical tools.

\section{Notes}

1 Mark Lawson, "How I Learned to Love Immersive Theatre," The Guardian, September 25, 2012.

2 Emily Brown and Paul Cairns, "A Grounded Investigation of Game Immersion," CHI 2004 Proceedings (New York: ACM Press, 2004), 1297-1300.

3 Oliver Grau, Virtual Art. From Illusion to Immersion (Cambridge, MA: MIT Press, 2003$), 17$.

4 Gareth White, "On Immersive Theatre," Theatre Research International 37.3 (2012): 233.

5 Dominic Arsenault and Martin Picard, "Le jeu vidéo entre dépendance et plaisir immersif: les trois formes d'immersion vidéoludique," paper presented at the symposium Le jeu vidéo: un phénomène social massivement pratiqué?, 75th congress of the ACFAS, Université du Québec à Trois-Rivières, 2007, 5.

6 Josephine Machon, Immersive Theatres: Intimacy and Immediacy in Contemporary Performance (Basingstoke: Palgrave MacMillan, 2013).

7 Sarah Rubidge, "Sensuous Geographies and Other Installations: Interfacing the Body and Technology," in Performance and Technology: Practices of Virtual Embodiment and Interactivity, eds. Susan Broadhurst and Josephine Machon (Basingstoke: Palgrave MacMillan, 2006), 113.

8 Frances Dyson, Sounding New Media. Immersion and Embodiment in the Arts and Culture (Ewing: University of California Press, 2009).

9 Josephine Machon, "Felix Barrett in Discussion with Josephine Machon," 2007, available online at http://people.brunel.ac.uk/bst/vol0701/felixbarrett/home.html, accessed January 4, 2013.

10 Kurt Vanhoutte et al., "Being Inside the Image. Heightening the Sense of Presence in a Video Captured Environment through Artistic Means: The Case of CREW," in Presence 2008: Proceedings of the 11th International Workshop on Presence in Padova, eds. Anna Spagnolli et al. (Padova: Libraria Universitaria Padova, 2008), 159-62. 
11 Marie-Laure Ryan, "Beyond Myth and Metaphor: Narrative in Digital Media," Poetics Today 23.4 (2002): 581-609.

12 Steve Dixon, Digital Performance (Cambridge, MA: MIT Press, 2007), 563.

13 Ryan, "Beyond Myth and Metaphor," 601.

14 Jeremy Douglass, quoted in Steve Benford and Gabriella Giannachi, Performing Mixed Reality (Cambridge, MA: MIT Press, 2011), 207.

15 Alice Bell and Astrid Ensslin, "II know what it was. You know what it was': Second-Person Narration in Hypertext Fiction," Narrative 19.3 (2011): 318.

16 Marie-Laure Ryan, Narrative as Virtual Reality: Immersion and Interactivity in Literature and Electronic Music (Baltimore, MD: John Hopkins University Press, 2001), 14.

17 Richard Gerrig, quoted in Marie-Laure Ryan, "Immersion vs. Interactivity: Virtual Reality and Literary Theory," Substance 28.2 (1999): 116.

18 Ryan, Narrative as Virtual Reality, 299.

19 Matthew Causey, Theatre and Performance in Digital Culture (London: Routledge, 2009), 15.

20 Elena Gorfinkel, quoted in Arsenault and Picard.

21 Grau, 13.

22 Felix Barrett, quoted in Machon. 